\title{
Experimental study of self-sustainable hybrid solar photovoltaic cleaning mechanism coupled with water distillation unit
}

\author{
Yash Guptaa $^{1}$, Sai Manoj Katakam ${ }^{2}$, Susheel Reddy Aligireddy ${ }^{3}$, Waseem Shameer ${ }^{4}$, \\ Deepali Atheaya ${ }^{5}$ \\ Department of Mechanical and Aerospace Engineering, Bennett University, \\ Tech Zone-II, Greater Noida 201310, U.P., India \\ ${ }^{1}$ Corresponding author \\ E-mail: ${ }^{1}$ yashyuptaa11@gmail.com, ${ }^{2}$ katakamsaimanoj9@gmail.com, \\ ${ }^{3}$ susheelreddyaligireddy@gmail.com, ${ }^{4}$ waseemshameer21@gmail.com, ${ }^{5}$ deepali.atheaya@bennett.edu.in
}

Received 25 October 2019; accepted 1 November 2019

DOI https://doi.org/10.21595/vp.2019.21140

Check for updates

Copyright (C) 2019 Yash Guptaa, et al. This is an open access article distributed under the Creative Commons Attribution License, which permits unrestricted use, distribution, and reproduction in any medium, provided the original work is properly cited.

\begin{abstract}
In the present research work a novel self-sustainable hybrid solar photovoltaic cleaning mechanism coupled with water distillation unit has been proposed. The experiments were conducted on the PV (photovoltaic) modules at Bennett University, Greater Noida A-block terrace from 7th to 13th October, 2019. Post installation, the average efficiencies of the solar PV module system with and without cleaning were compared to obtain a hike by $1.34 \%$. The water used for cleaning was recycled using a single slope basin type solar still which indicated a working efficiency of $67.94 \%$. On an average the solar still yielded 5.3 Litres of pure water every day during the experiment with a TDS (total dissolved solids) level of $104 \mathrm{ppm}$.
\end{abstract}

Keywords: photovoltaic modules, cleaning mechanism, water distillation unit, efficiency.

\section{Introduction}

Current solar panels of commercial viability have a limited efficiency. The output of solar PV system is majorly affected by dust particles, which get accumulated on the surface of the panels. Hence, the maximum power output reduces. To harness maximum radiation the panels are needed to be cleaned regularly. Most popular method of cleaning the solar panel is through manual labor which is time taking, cumbersome with a risk of damage to the expensive solar panels by the unskilled labor. Water which is the basic need for human survival is almost toxic with harmful chemical, hence only $1 \%$ potable water is left on earth and which is why purification is important.

Typically, the efficiency of mono crystalline panel is $17-19 \%$, while the polycrystalline ones deliver at 13-17\%. Even the world's most effective solar cells are just $44.5 \%$ efficient. The highest performing solar panel in the U.S. market today is, SunPower X21-345 with a module efficiency of $22.8 \%$. Apart from this, certain environmental factors like shading, high ambient temperatures, wrong orientation, dust accumulation, climatic conditions have an adverse effect on the efficiency too [1]. Solar stills have been one of the most conventional methods of purifying water since ages. They are proven to be efficiency in getting rid of salts like sodium, calcium, arsenic; bacterias like cholera, e.coli; parasites and other heavy metals [2]. [3] gave a Heliostats cleaning mechanism but the robots involved required charging separately. Later on [4] proposed the gekko solar and farm bots which were automatic and flexible in design but had a limitation only up to $30^{\circ}$ to $45^{\circ}$, alongside with heavy load interface on the surface of panels. [5] Came up with a linear piezoelectric actuator based solar panel cleaning mechanism with minimum gears which reduced load on the surface of the panels, but it was a complex system. [6] Introduced electrostatic biasing for dust particles on the surface of the solar panels which required no water but the charge input was very high. Talking about the recent trends in solar distillation unit, [7] shows a double slope solar still with phase changing material and a low efficiency of 30-40\%. [8] Proposes basin type still installed with flat plate collectors to enhance the efficiency of the system 
but construction for the same is very complex. The most ideal solar still was proposed by [9] in 2011, but with the application of harmful lauric acid.

The main objective of this research is to investigate and develop an automatic fully sustainable hybrid self-cleaning mechanism for the PV Modules and a solar powered water distillation unit so that the process can become more reliable, fast, eco-friendly, and labor-free. Such systems have high utility in the chemical and manufacturing industries as well as are able to meet the increasing energy and fresh water demands.

\section{Description of experimental setup}

The self-sustainable hybrid solar photovoltaic cleaning mechanism coupled with water distillation comprises of two sections:

(a) The solar panel cleaning mechanism: a schematic diagram is shown in Fig. 1. The set of 4 polycrystalline solar panels ( 72 solar cells in each) are connected in series, inclined at $28^{\circ}$. A solar inverter is connected, which converts the input D.C. current from the solar panels to A.C. current. It is necessary to wash the dust accumulated on the surface of the solar panels and subsequently reduce its surface temperature (Solar panels are marked at $25^{\circ} \mathrm{C}$, and effect of temperature can be seen here [10]). Water is drawn out from a large storage tank with the help of an A.C. motor pump, powered by the solar panels itself. Water travels up through a branched network of pipes to come out through 12 brass nozzles (Fan angle $=0^{\circ}$ ) which are equidistantly fixed on the upper edge of the PV module setup (Stand-off distance $=0$, Shear flow to reduce direct impact of water on surface). Water gushes out through these nozzles washing maximum exposed area and flushes the settled dust all at once. The flow of water through the pump is controlled by a time switch which operates 6 times during the day: 6:00 AM, 8:00 AM, 10:00 AM, 12:00 PM, 2:00 PM, 4:00 PM. The pump operates for 30 seconds every time it is switched on. The dirty water at the end of the entire cleaning process is collected on the edges of the PV module surface and then led into a small filter cone eventually connecting into the solar powered distillation unit.

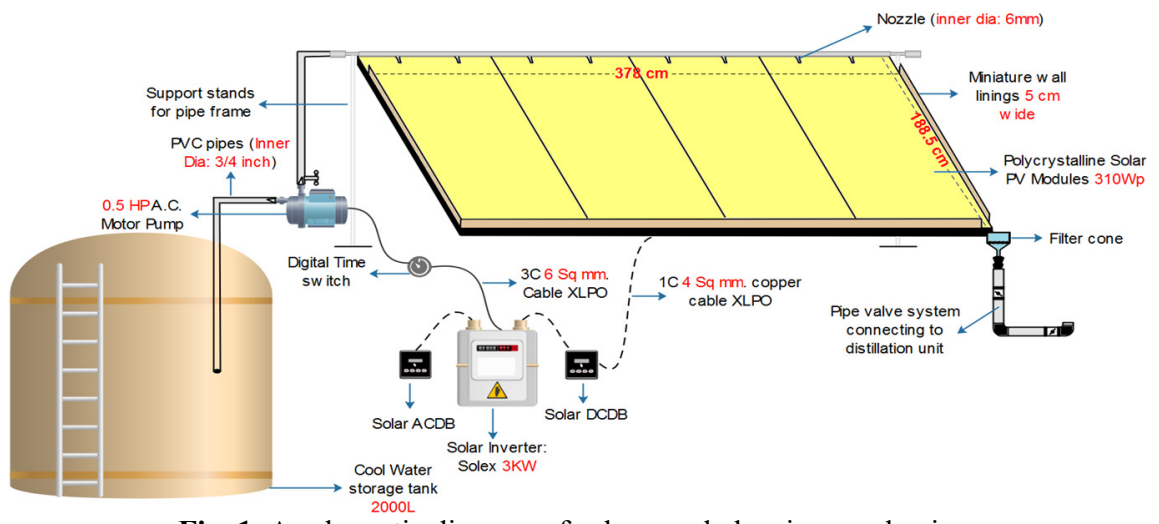

Fig. 1. A schematic diagram of solar panel cleaning mechanism

(b) The solar powered distillation unit: the construction for the single slope basin type solar still can be viewed in Fig. 2. The dirty water which has to be distilled is poured in through a pipe inlet to partially fill the basin whose floor is blackened to increase solar energy absorption. The cover of the still is a slope (angle $=28^{\circ}$ ), made out from glass which is transparent, clean and non-absorbent of water. Glass cover is supported by fiber sticks through its length. The side rigid walls, made up of wood, have internal thermocol $(k=0.02 \mathrm{~W} / \mathrm{m}-\mathrm{K})$ coating for better insulation in order to prevent heat loss from inside of the still to the ambient atmosphere. A PVC (Poly vinyl chloride) channel towards the bottom underlining of the glass slope ensures distillate collection which joins into a distillate tank. After being exposed to the sun, general heat transfer in the system initiates: Convection in water molecules during heating phase, followed by evaporation and finally 
condensation of the vapor to liquid water droplets on the glass surface. These droplets, as a result of the slanted surface, trickle down and get collected in that channel. This is pure distilled potable water. An outlet for brackish water is made at bottom corner. This water is used for domestic plantation.

The actual images of the experimental setup are provided in Fig. 3 and Fig. 4 respectively.

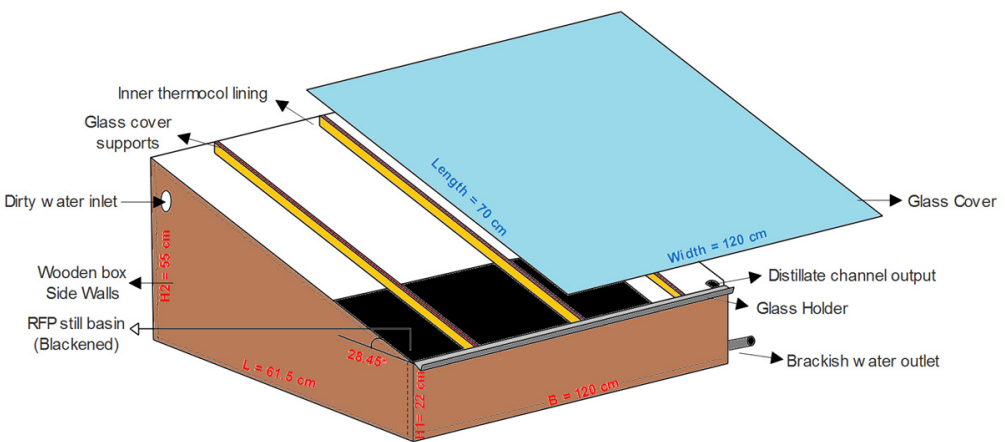

Fig. 2. A schematic diagram of proposed single slope basin type solar still - water distillation unit

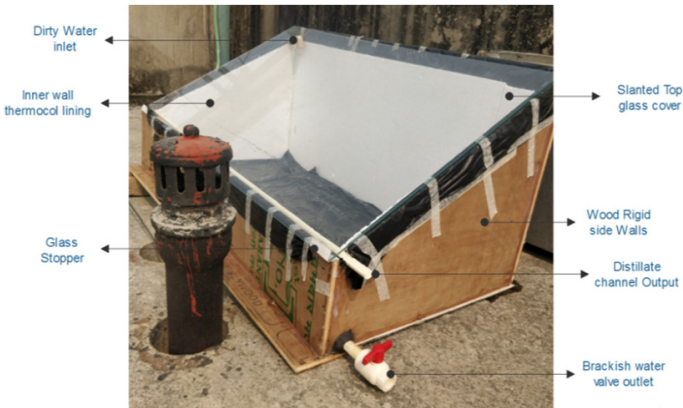

Fig. 3. Picture showing the solar still

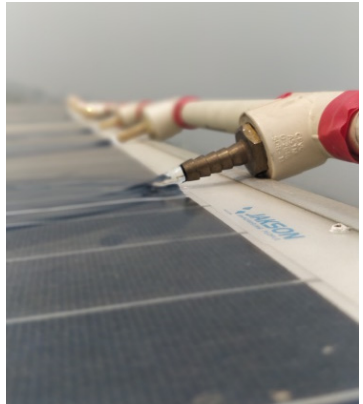

Fig. 4. Picture of nozzles for cleaning the PV modules

\section{Governing equations}

The expression of aperture area $A_{c}$ of the PV Module collector is given by $A_{c}=w \times l \mathrm{~m}^{2}=$ $7.7616 \mathrm{~m}^{2}$.

The expression of maximum efficiency $\eta$, at $\mathrm{STC}\left(25^{\circ} \mathrm{C}\right)$ and incident flux, $E$ is given by, $\eta=P_{m} /\left(E \times A_{C}\right) \times 100 \%$, here Max Power, $P_{m}=310 \mathrm{~W}$ and $E=1000 \mathrm{~W} / \mathrm{m}^{2}$, hence $\eta=16.00 \%$.

The expression to calculate solar cell fill factor $F F$ is as follows: $F F=P_{m} /\left(V_{o c} \times I_{o c}\right)$, here open circuit: voltage $V_{o c}=45.5 \mathrm{~V}$, current $I_{o c}=8.85 \mathrm{~A}$, hence $F F=0.7$.

The expression for instantaneous efficiency $\eta_{\text {inst }}$ of the module at any temperature $T_{\text {inst }}$ is:

$\eta_{\text {inst }}=\eta-\left[\left(T_{\text {inst }}-25\right) \times\right.$ Temperature coefficient of $\left.P_{m}\right]$,

were, temperature coefficient of $P_{m}=-0.39 \% /{ }^{\circ} \mathrm{C}$.

The expression for electrical efficiency $\left(\eta_{e}\right)$ of the module:

$\eta_{e}=\frac{V_{o c} \times I_{o c} \times F F}{\text { Solar irradiance } \times A_{c}}$.

In single slope solar stills, hourly distillate output per unit area of glass $\dot{m}_{e w}[11]$ is given by $\dot{m}_{e w}=\left(q_{e w} \times 3600\right) / L \mathrm{Kg} / \mathrm{m}^{2}-\mathrm{hr}$. 
The expression to calculate latent heat of evaporation $L$, of water [12] is as follows: $L=$ $3.1615 \times 10^{6} \times\left[1-7.6160 \times 10^{-4} \times T\right], \mathrm{J} / \mathrm{Kg}-\mathrm{K}$ when $T>70{ }^{\circ} \mathrm{C}$, and $L=2.4935 \times 10^{6} *$ $\left[1-9.4479 \times T^{-4}+1.3132 \times 10^{-7} \times T^{2}-4.7974 \times 10^{-9} \times T^{3}, \mathrm{~J} / \mathrm{Kg}-\mathrm{K}\right.$ when $T<70{ }^{\circ} \mathrm{C}$.

Hourly evaporation per square meter, $q_{e w}[13]$ expression is given with the following equation: $q_{e w}=0.0163 h_{c w} \times\left(P_{w}-P_{g}\right) \mathrm{W} / \mathrm{m}^{2}$, where $h_{c w}$ is convective heat transfer coefficient and $P$ is the partial pressures at glass and water temperatures.

Efficiency of the solar still $\epsilon_{\text {still }}$ expression is obtained as:

$$
\epsilon_{\text {still }}=\frac{\text { Actual amount of distilled water }}{\text { Theoretical amount of distiled water }} .
$$

Table 1 describes the system specification.

Table 1. Parts involved and their specifications

\begin{tabular}{|c|c|c|c|}
\hline Sl. No. & Part & Dimension/Quantity & Comments \\
\hline 1. & Cool Water Tank & Capacity: $2000 \mathrm{~L}$ & Material: concrete and bricks \\
\hline 2. & Pipes & Length: $17 \mathrm{~m}$ I.D. $=0.019 \mathrm{~m}$ & Material: PVC \\
\hline 3. & A.C. Motor pump & Power usage: $0.5 \mathrm{H} . \mathrm{P}$. & Model: V-Guard H90 Revo series \\
\hline 4. & Elbow/ T joints & Quantity: 3 each & Material: PVC \\
\hline 5. & Nozzles & Quantity: 12 , I.D. $=0.006 \mathrm{~m}$ & Material: Brass, Round cross section \\
\hline 6. & Time switch & Digital resolution: $1 \mathrm{~s}$ & Model: Frontier TM61942 \\
\hline 7. & Solar Panel & W: $3.96 \mathrm{~m}, \mathrm{~L}: 1.96 \mathrm{~m}$ & Model: JP 24 X 310 Jackson \\
\hline 8. & Solar Inverter & Solex INV $310 \mathrm{~W}$ & Material: PVC \\
\hline 9. & Water collector & $0.076 \mathrm{~m}$ Dia, half section & Material: RFP, Carbon sink filter \\
\hline 10. & Filtration pipe & Dia: $0.03 \mathrm{~m}$, Length: $3.05 \mathrm{~m}$ & Material: Thermocol, k: $0.02 \mathrm{~W} / \mathrm{m}-\mathrm{K}$ \\
\hline 11. & Inner Wall lining & Thickness: $0.012 \mathrm{~m}$ & Material: PVC, Half cut round pipe \\
\hline 12. & Distillate Channel & Length: $1.5 \mathrm{~m}$ & Material: Glass, k: $1.00 \mathrm{~W} / \mathrm{m}-\mathrm{K}$ \\
\hline 13. & Top cover & Thickness: $0.003 \mathrm{~m}$ & Material: RFP, k: $0.20 \mathrm{~W} / \mathrm{m}-\mathrm{K}$ \\
\hline 14. & Base & Thickness: $0.012 \mathrm{~m}$ & Aerosol spray \\
\hline 15. & Black paint & $0.4 \mathrm{~L}$ & Immersion length: 2 inches \\
\hline 16. & TDS Meter & Resolution $=1 \mathrm{PPM}$ & DSI8B20 water proof probe \\
\hline 17. & Thermocouple & Range: -55 to $125^{\circ} \mathrm{C}$ & Model: TM-750 Solar power meter \\
\hline 18. & Solarimeter & Accuracy: $\pm 10 \mathrm{~W} / \mathrm{m}^{2}$ & \\
\hline
\end{tabular}

\section{Results and discussions}

The experiment conducted for the given parameters are from 7th to 13th October, 2019 and the readings are noted in Table 2. Eq. (1) and Eq. (2) have been used to calculate efficiencies before and after cleaning the solar panels. The subsequent data can be viewed.

Table 2. Experimental readings for solar panel cleaning mechanism

\begin{tabular}{|c|c|c|c|c|c|c|}
\hline $\begin{array}{c}\text { Time } \\
(\mathrm{Hrs})\end{array}$ & $\begin{array}{c}\text { Ambient } \\
\text { Temperature } \\
\left({ }^{\circ} \mathrm{C}\right)\end{array}$ & $\begin{array}{c}\text { Solar cell } \\
\text { temperature } \\
\text { without cleaning } \\
\text { system }\left({ }^{\circ} \mathrm{C}\right)\end{array}$ & $\begin{array}{c}\text { Solar cell } \\
\text { temperature with } \\
\text { cleaning system } \\
\left({ }^{\circ} \mathrm{C}\right)\end{array}$ & $\begin{array}{c}\text { Power output } \\
\text { without } \\
\text { cleaning } \\
\text { system }(\mathrm{W})\end{array}$ & $\begin{array}{c}\text { Power output } \\
\text { with cleaning } \\
\text { system }(\mathrm{W})\end{array}$ & $\begin{array}{c}\text { Solar } \\
\text { Irradiance } \\
\left(\mathrm{W} / \mathrm{m}^{2}\right)\end{array}$ \\
\hline $6: 00$ & 22 & 23.5 & 22.5 & 240 & 257 & 1210 \\
\hline $8: 00$ & 23 & 33.9 & 31 & 354 & 399 & 1260 \\
\hline $10: 00$ & 28 & 44 & 41.5 & 557 & 628 & 1300 \\
\hline $12: 00$ & 32 & 51 & 48 & 779 & 881 & 1450 \\
\hline $14: 00$ & 34 & 49 & 46.5 & 682 & 757 & 1600 \\
\hline $16: 00$ & 32 & 38 & 36 & 341 & 383 & 1460 \\
\hline $18: 00$ & 29 & 32 & 30 & 275 & 304 & 1310 \\
\hline
\end{tabular}

The plots for the variation in ambient temperature, PV module temperatures with and without 
cleaning are shown in Fig. 5. A relative comparison of the power output of the modules with and without cleaning mechanism is illustrated in Fig. 6.

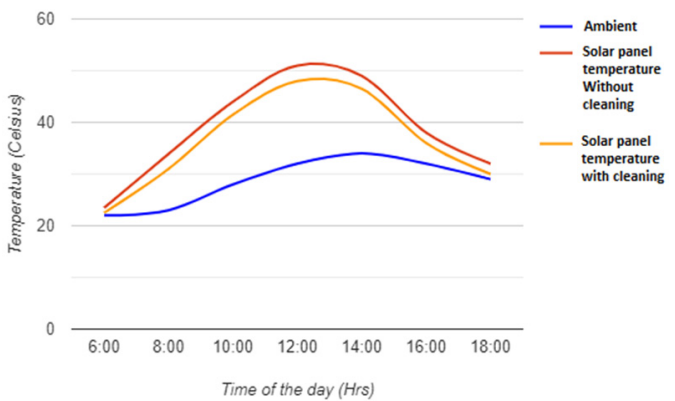

Fig. 5. Variation of temperatures with time

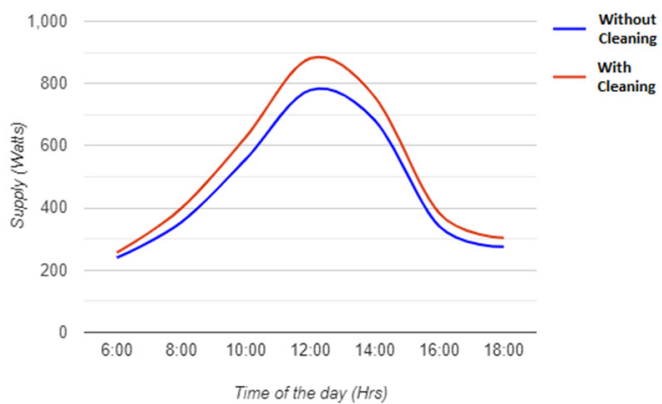

Fig. 6. Comparing power outputs with and without cleaning

Data recorded for the solar still can be obtained from Table 3, here $T_{w}$ is temperature of water in solar still and $T_{g}$ is temperature of glass cover of solar still.

After running the cleaning system 6 times in a day, the total amount of dirty water entering the solar still is 48 liters. The volume of distilled water obtained was 5.3 liters. The TDS (Total dissolved solids) meter is used to check the portability of the water. The purity of the distillate obtained is 104 ppm.

The efficiency of the solar panels with and without the cleaning system is shown in Table 4. The graph showing a relative comparison is illustrated in Fig. 7.

It was observed that the amount of pure water that must be obtained is $7.8 \mathrm{~L}$ and experimentally distilled water obtained was $5.3 \mathrm{~L}$. The efficiency of the solar still is calculated by Eq. (3) and is found to be $67.94 \%$.

Table 3. Data and readings for solar still

\begin{tabular}{|c|c|c|c|c|c|}
\hline Time $(\mathrm{Hrs})$ & $T_{g}\left({ }^{\circ} \mathrm{C}\right)$ & $T_{w}\left({ }^{\circ} \mathrm{C}\right)$ & $L(\mathrm{~J} / \mathrm{Kg}-\mathrm{K})$ & $q_{e w}\left(\mathrm{~W} / \mathrm{m}^{2}\right)$ & $\dot{m}_{e w}\left(\mathrm{Kg} / \mathrm{m}^{2}-\mathrm{hr}\right)$ \\
\hline $6: 00$ & 22 & 27 & 2204413.9 & 37.22 & 0.062 \\
\hline $8: 00$ & 26 & 41.5 & 2153772.7 & 185.06 & 0.311 \\
\hline $10: 00$ & 32.5 & $52 . .5$ & 2114932.6 & 342.75 & 0.577 \\
\hline $12: 00$ & 41.2 & 61.4 & 2082800.4 & 489.87 & 0.825 \\
\hline $14: 00$ & 48.5 & 65.3 & 2098160.5 & 470.34 & 0.792 \\
\hline $16: 00$ & 40.3 & 52.7 & 2142960.5 & 250.75 & 0.422 \\
\hline $18: 00$ & 32.4 & 40.9 & 2162392.2 & 114.57 & 0.193 \\
\hline
\end{tabular}

Table 4. Efficiency comparison of the solar panel cleaning mechanism \begin{tabular}{|l|l|l|l|}
\hline Sl no. & Time of the day & Efficiency of the modules before cleaning & Efficiency of the modules after cleaning \\
\hline
\end{tabular}

\begin{tabular}{|c|c|c|c|}
\hline 1. & $6: 00 \mathrm{AM}$ & $13.25 \%$ & $14.2 \%$ \\
\hline 2. & $8: 00 \mathrm{AM}$ & $12.7 \%$ & $14.35 \%$ \\
\hline 3. & $10: 00 \mathrm{AM}$ & $12.33 \%$ & $13.9 \%$ \\
\hline 4. & $12: 00 \mathrm{PM}$ & $11.05 \%$ & $12.5 \%$ \\
\hline 5. & $2: 00 \mathrm{PM}$ & $9.99 \%$ & $11.1 \%$ \\
\hline 6. & $4: 00 \mathrm{PM}$ & $10.95 \%$ & $12.3 \%$ \\
\hline 7. & $6: 00 \mathrm{PM}$ & $12.2 \%$ & $13.5 \%$ \\
\hline
\end{tabular}




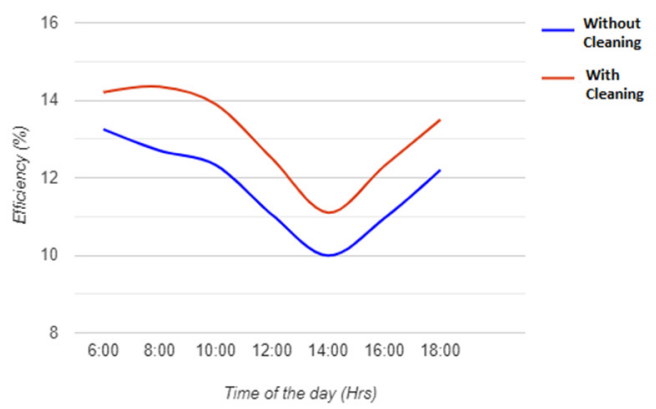

Fig. 7. Comparison of average efficiencies of the cleaning mechanism from 7th to 13 th October, 2019

\section{Conclusions}

From the experimental study in this paper the following conclusions have been made:

1) Maximum solar irradiance during the day time is between 12 and $4 \mathrm{pm}$, hence during that time the evaporation in solar still increases and conversion rate of PV modules due to high temperatures decreases.

2) Overall average efficiency hike after installing the solar panel cleaning mechanism was observed as $1.34 \%$.

3) The overall average efficiency of the solar still was calculated to be $67.94 \%$.

\section{References}

[1] Ghazi Sanaz, Ip Kenneth The effect of weather conditions on the efficiency of PV panels in southeast of UK. Renewable Energy, Vol. 69, 2014, p. 50-59.

[2] Mehta A., Arjun Vyas, Bodar N., Lathiya D. Design of solar distillation system. International Journal of Advanced Science and Technology, Vol. 29, 2011, p. 67-74.

[3] Michael H., Daniel M., Antonio G., Candido G. Hector - Heliostat Cleaning Team-Oriented Robot. SolarPlace, Granada, 2011.

[4] Kosumdok Levent, Von Flüe Marc Serbot Swiss Innovations. SERBOT AG, 2012, https://www.serbot.ch/en/solar-panels-cleaning/gekko-solar-robot.

[5] Lu Xiaolong, Zhang Qi, Hu Junhui A linear piezoelectric actuator based solar panel cleaning system. Energy, Vol. 60, 2013, p. 401-406.

[6] Ibrahim Adabara, Abdurrahman Shuaibu, Abdurrashid Hassan Design and implementation of an electrostatic precipitator and its cleaning system for small scale combustion. Iranian Journal of Scientific Research, Vol. 1, 2017, p. 213-224.

[7] Raveena Ramteke J., Aishwarya Dhurwey R., Harshit Borkar B., Adarsh Rai J., Ankit Malviya, Ajay Mate A., Mohammad Aftab Sheikh, Vikrant Katekar P. Recent trends in solar distillation. International Journal for Research in Applied Science and Engineering, Vol. 4, 2016, p. 2321-9653.

[8] Anwarul Islam Sifat, Md Milon Uddin Water distillation method using solar power. Proceedings of the International Conference on Mechanical Engineering and Renewable Energy, 2015.

[9] Al-Hamadani A.-A.-F., Shukla S. K. Water distillation using solar energy system with lauric acid as storage medium. International Journal of Energy Engineering, Vol. 1, Issue 1, 2011, p. 1-8.

[10] Amelia R., Mohd Yusoff, Zhe Leow Wai, Irwanto Muhammad Investigation of the effect temperature on photovoltaic (PV) panel output performance. International Journal on Advanced Science, Engineering and Information Technology, Vol. 6, 2016, p. 2088-5334.

[11] Abhay Agrawal, Rana R. S., Pankaj Srivastava K. Heat transfer coefficients and productivity of a single slope single basin solar still in Indian climatic condition: experimental and theoretical comparison. Resource efficient Technologies, Vol. 3, 2017, p. 466-482.

[12] Tiwari G. N. Overall thermal efficiency of solar still. Solar Energy: Fundamentals, Design, Modelling and Applications. Narosa Publishing House, Delhi, 2002.

[13] Giustini Giovanni, Jung Satbyoul, Kim Hyungdae, Walker S. P. Evaporative thermal resistance and its influence on icroscopic bubble growth. International Journal on Heat and Mass Transfer, Vol. 101, 2016, p. 733-741. 